\title{
WHO sponsored collaborative studies on nutritional anaemia in India
}

\section{The effects of ascorbic acid and protein supplementation on the response of pregnant women to iron, pteroylglutamic acid and cyanocobalamin therapy}

\author{
BY V. I. MATHAN, S. J. BAKER, ${ }^{*}$ S. K. SOOD, $†$ K. RAMACHANDRAN \\ AND V. RAMALINGASWAMI \\ Wellcome Research Unit, Christian Medical College Hospital, Vellore, Tamil Nadu and \\ Department of Pathology and Biostatistics, All-India Institute of Medical Sciences, \\ New Delhi
}

(Received 17 April 1979 - Accepted 23 May 1979)

\begin{abstract}
I. A study was conducted in two centres in southern and northern India of the effects of the addition of ascorbic acid and protein supplements to iron, pteroylglutamic acid and cyanocobalamin, in the prophylaxis and treatment of anaemia of pregnancy.

2. A dose of $500 \mathrm{mg}$ ascorbic acid/d had no beneficial effect. Women who received $15 \mathrm{~g}$ calcium caseinate/d showed a superior haematological response. The reasons for this are unknown, but are more likely attributable to an increased absorption of the supplemental iron than to the correction of a protein deficiency.
\end{abstract}

The previous study in this series (Sood et al., 1975) on the prophylaxis of anaemia of pregnancy in Indian women showed that a significant proportion of women remained anaemic even after receiving a dialy oral supplement of $120-240 \mathrm{mg}$ elemental iron and $5 \mathrm{mg}$ pteroylmonoglutamic acid, together with parenteral cyanocobalamin, for IO- 12 weeks during the latter part of pregnancy. It was considered that the persisting high prevalence of anaemia was probably due to inadequate Fe absorption but the possibility of deficiency of some other nutrient such as protein could not be excluded. The present study was therefore designed to elucidate the effects of ascorbic acid (a promoter of Fe absorption) and protein supplementation on the haematological response of pregnant women to oral Fe therapy.

\section{MATERIALS AND METHODS}

As in the previous study (Sood et al. 1975) the trial was carried out both in Vellore in southern India and Delhi in northern India. Pregnant women who agreed to collaborate were admitted to the trial at $26 \pm 2$ weeks of gestation. Women who had received haematinics during the previous 6 months, who had chronic illnesses, or who had a haemoglobin concentration below $50 \mathrm{~g} / 1$ were excluded. The participating women were divided into one of three strata according to their haemoglobin concentrations $(\mathrm{g} / \mathrm{l}: 50-79,80-109,110$ or above) and within each stratum the subjects were randomly allocated in equal proportion to one of the following treatment groups: (1) oral ferrous sulphate (Fersolate) providing $120 \mathrm{mg}$ elemental $\mathrm{Fe}$ in one daily dose, oral pteroylmonoglutamic acid $(5 \mathrm{mg} / \mathrm{d})$ and cyanocobalamin (provided by Glaxo Laboratories, India, Ltd) (100 $\mu \mathrm{g}$ intramuscularly once every I4 d); (2) as group I, plus $500 \mathrm{mg}$ ascorbic acid (Celin, provided by Glaxo Laboratories, India, Ltd) daily; (3) as in group I, plus $15 \mathrm{~g}$ protein as calcium caseinate (Casilan,

* Present address: Department of Medicine, St Boniface Hospital, Winnipeg, Manitoba, Canada.

$\dagger$ Present address: Faculty of Medicine, University of Garyounis, P.O. Box I45I, Benghazi, Libya. 
V. I. MATHAN AND OTHERS

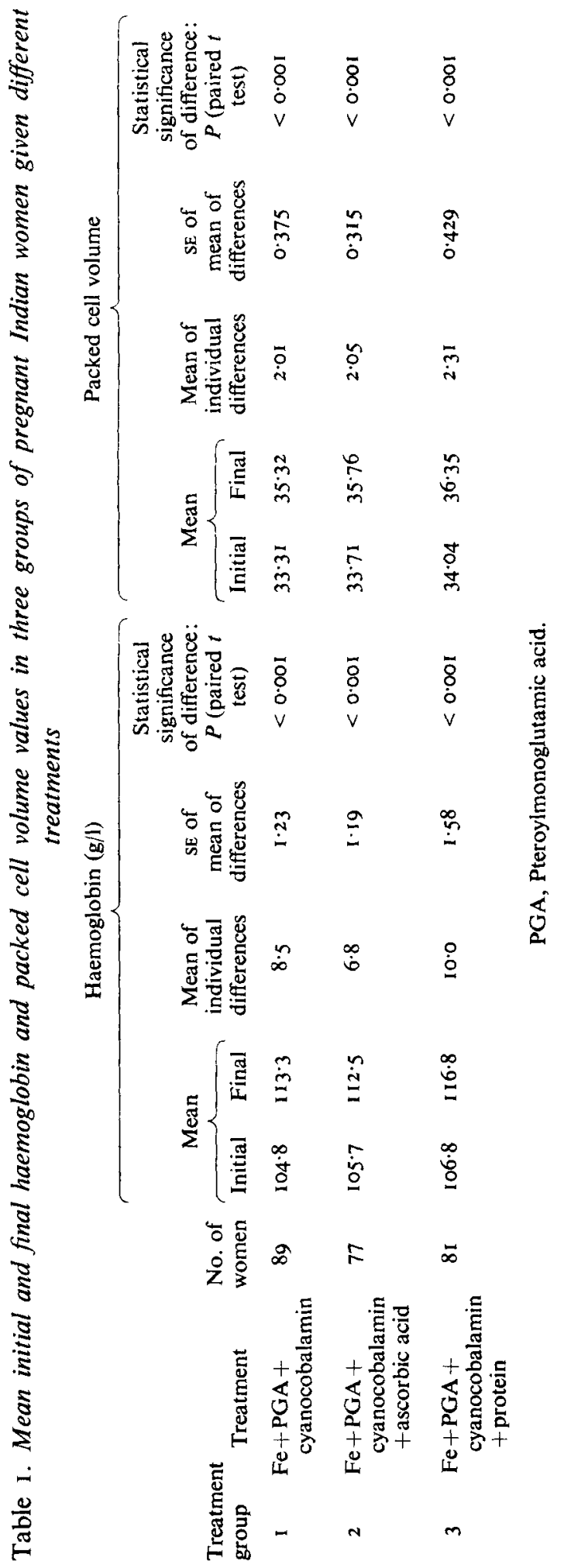




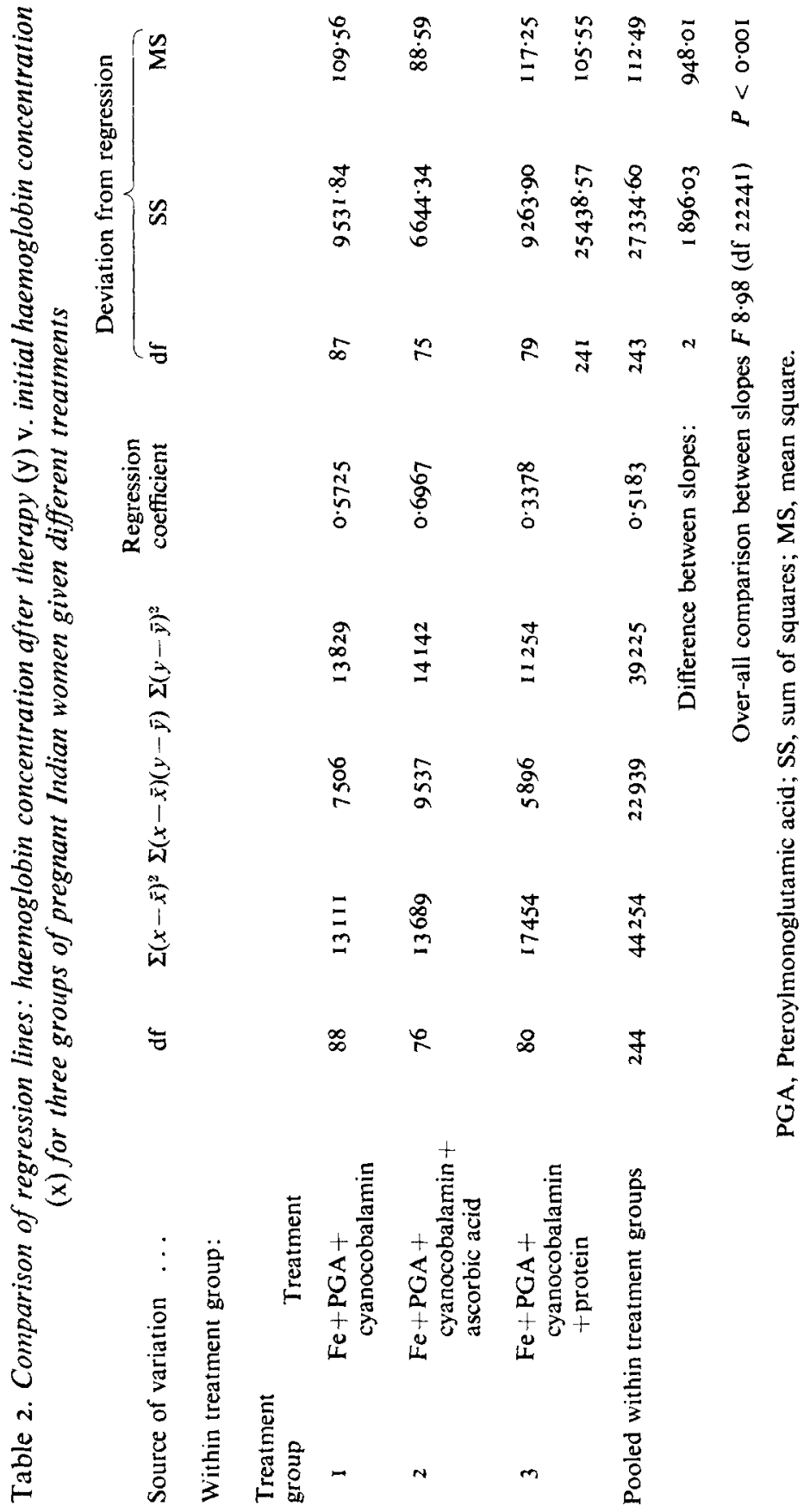




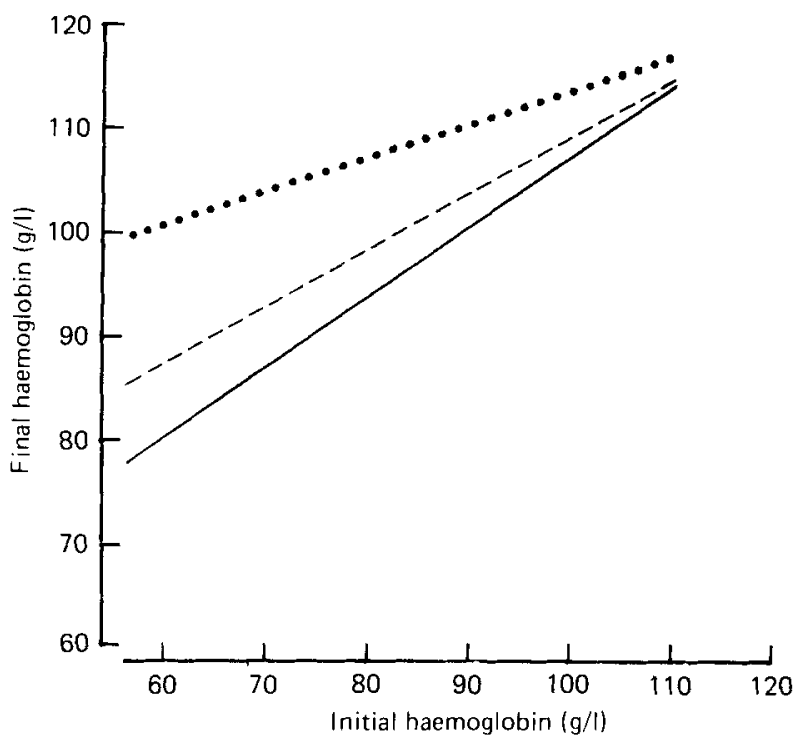

Fig. I. Regression lines of final haemoglobin concentration $(g / l) v$. initial haemoglobin concentration $(\mathrm{g} / \mathrm{l})$ for the three groups of pregnant Indian women given different treatments. - - , Group I given iron, pteroylmonoglutamic acid and cyanocobalamin; - - group 2 given iron, pteroylmonoglutamic acid, cyanocobalamin and ascorbic acid; $\cdots$, group 3 given iron, pteroylmonoglutamic acid and protein.

provided by Glaxo Laboratories, India, Ltd) given daily as a flavoured drink along with the tablets.

All oral therapy was given once per day, $6 \mathrm{~d}$ per week for I0-I 2 weeks, under the direct supervision of a public health nurse. The medication was given at random during the day and bore no constant relationship to the time of meals. Venous blood was withdrawn under standard conditions with a minimum of stasis at the beginning and end of the trial period, 2-4 d after ingestion of the last tablet. Haemoglobin was estimated by the cyanmethaemoglobin method (Dacie, 1956) and checked periodically against an international reference standard (provided by Dr S. M. Lewis). The packed cell volume was determined by the microhaematocrit method. Total serum proteins were measured by the Biuret method. For the patients studied in Vellore the serum Fe was measured by the method recommended by the International Committee for Standardization in Haematology (1971) and the serum Fe-binding capacity was determined by the isotopic method of Herbert et al. (I966).

Ethical considerations. All women were aware that they were participating in a therapeutic trial and were free to withdraw from the study at any point without detriment to the antenatal care offered to participants.

\section{RESULTS}

As in the previous study (Sood et al. 1975) the results in the two centres were in close agreement. The results were therefore pooled and the combined results are presented.

The initial and final mean haemoglobin concentration, mean packed cell volume and mean of individual differences in each of the groups are shown in Table I. In all groups there was a significant rise in haemoglobin concentration and packed cell volume after therapy $(P<0.00 \mathrm{I})$. The rise was highest in group 3 which received the protein supplement. The least response occurred in group 2 which received the ascorbic acid supplement.

As in the previous study (Sood et al. 1975), the magnitude of the rise in haemoglobin 
Table 3. Estimated regression function and expected mean haemoglobin concentration $(\mathrm{g} / \mathrm{l})$ after therapy $(\mathrm{y}) \mathrm{v}$. initial haemoglobin concentration $(\mathrm{x})$ for three groups of pregnant Indian women given different treatments

\begin{tabular}{|c|c|c|c|c|c|c|c|c|}
\hline \multirow{2}{*}{$\begin{array}{l}\text { Treatment } \\
\text { group }\end{array}$} & \multirow{2}{*}{ Treatment } & \multirow{2}{*}{$\begin{array}{l}\text { Estimated } \\
\text { regression } \\
\text { function }\end{array}$} & \multicolumn{6}{|c|}{$\begin{array}{l}\text { Expected mean haemoglobin }(\mathrm{g} / \mathrm{l}) \text { after therapy } \\
\text { with initial haemoglobin of: }\end{array}$} \\
\hline & & & 60 & 70 & 80 & 90 & 100 & IIO \\
\hline 1 & $\begin{array}{l}\mathrm{Fe}+\mathrm{PGA}+ \\
\text { cyanocobalamin }\end{array}$ & $y=53.302+5.725 x$ & $87 \cdot 7$ & $93 \cdot 4$ & $99 \cdot 1$ & 104.8 & 110.6 & I I $6 \cdot 3$ \\
\hline 2 & $\begin{array}{l}\mathrm{Fe}+\mathrm{PGA}+ \\
\text { cyanocobalamin } \\
\text { + ascorbic acid }\end{array}$ & $y=38.859+6.967 x$ & $80 \cdot 7$ & 87.6 & $94 \cdot 6$ & $101 \cdot 6$ & $108 \cdot 5$ & 115.5 \\
\hline 3 & $\begin{array}{l}\mathrm{Fe}+\mathrm{PGA}+ \\
\text { cyanocobalamin } \\
\quad+\text { protein }\end{array}$ & $y=80 \cdot 723+3 \cdot 378 x$ & IOI $\cdot 0$ & $104 \cdot 4$ & $107 \cdot 7$ & III I I & 114.5 & $117 \cdot 9$ \\
\hline
\end{tabular}

PGA, Pteroylmonoglutamic acid.

concentration after therapy was inversely related to the initial haemoglobin concentration. Hence regression functions of final haemoglobin concentration $v$. initial haemoglobin concentration were estimated by the least square method (Table 2, Fig. I). The differences in the slope of the regression lines were found to be significant $(F 8.98, P<0.001)$. In view of this, separate regression functions for each of the treatment groups were estimated, and on the basis of initial haemoglobin concentration the expected mean haemoglobin concentration was calculated (Table 3).

The mean $( \pm \mathrm{SE})$ rise in mean corpuscular haemoglobin concentration (MCHC) after treatment in the three groups was $0.52 \pm 0.244(P<0.05), 0.03 \pm 0.211(P>0.05)$ and $0.90 \pm 0.264(P<0.001)$ respectively. All three therapeutic regimens resulted in a significant rise in the mean values of the serum Fe and transferrin saturation (Table 4 ).

In all the groups there was a slight fall in the mean concentration of serum protein but this only achieved significance in group 3 (Table 5).

\section{DISCUSSION}

In the present study a placebo group was not included since the objective was to determine whether the additional administration of ascorbic acid or protein would produce a greater rise in haemoglobin concentration than could be obtained with $\mathrm{Fe}$, pteroylglutamic acid and cyanocobalamin.

As in the previous study (Sood et al. 1975) the women in group I who received Fe, pteroylglutamic acid and cyanocobalamin during the last trimester of pregnancy showed a significant rise in mean haemoglobin, packed cell volume, $\mathrm{MCHC}$, serum Fe and percentage saturation of transferrin.

In the women of group 2 who received $500 \mathrm{mg}$ ascorbic acid in addition to $120 \mathrm{mg} \mathrm{Fe}$, pteroylglutamic acid and cyanocobalamin, the haematological response was somewhat less than that in the women in group $\mathrm{I}$, and no benefit was demonstrable from the addition of ascorbic acid. It is noteworthy that in this group significantly more women withdrew from the trial due to the development of gastrointestinal symptoms than in the other groups. A similar finding has been reported by Hallberg et al. (1966). It has been shown by several investigators (Apte \& Venkatachalam, I965; Sayers et al. 1973; Björn-Rasmussen \& Hallberg, 1974) that addition of ascorbic acid to the diet will enhance absorption of both native vegetable Fe and of added fortification-Fe. However, from the practical point of 
V. I. MAthan AND Others

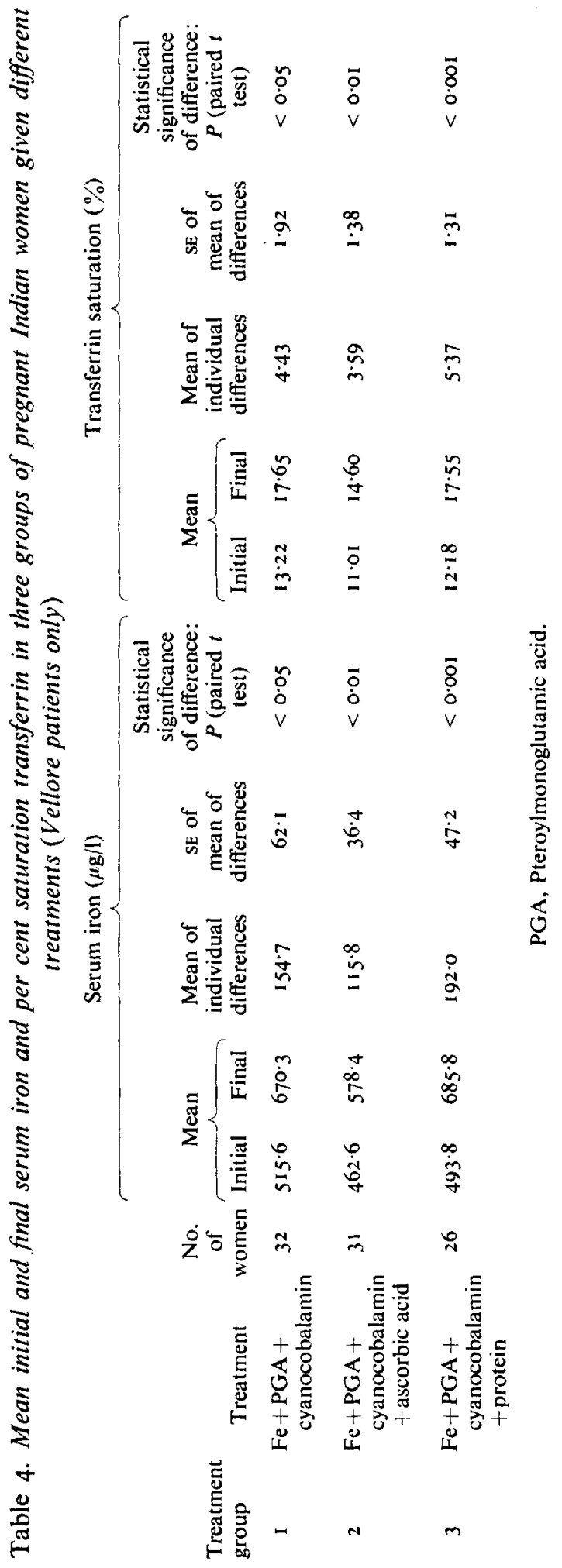


Table 5. Mean initial and final serum protein values $(\mathrm{g} / \mathrm{l})$ in three groups of pregnant Indian women given different treatments

\begin{tabular}{|c|c|c|c|c|c|c|c|}
\hline \multirow{2}{*}{$\begin{array}{l}\text { Treatment } \\
\text { group }\end{array}$} & \multirow[b]{2}{*}{ Treatment } & \multirow{2}{*}{$\begin{array}{l}\text { No. of } \\
\text { women }\end{array}$} & \multicolumn{2}{|c|}{$\begin{array}{l}\text { Serum protein } \\
(\mathrm{g} / \mathrm{l})\end{array}$} & \multirow{2}{*}{$\begin{array}{l}\text { Mean of } \\
\text { individual } \\
\text { differences }\end{array}$} & \multirow{2}{*}{$\begin{array}{c}\text { SE of } \\
\text { mean of } \\
\text { differences }\end{array}$} & \multirow{2}{*}{$\begin{array}{c}\text { Statistical } \\
\text { significance } \\
\text { of difference: } \\
P \text { (paired } t \\
\text { test) }\end{array}$} \\
\hline & & & Initial & Final & & & \\
\hline 1 & $\underset{\text { cyanocobalamin }}{\mathrm{Fe}+\mathrm{PGA}+}$ & $6 I$ & $63 \cdot 5$ & $62 \cdot 7$ & -0.8 & I. 808 & 0.7 (NS) \\
\hline 2 & $\begin{array}{l}\mathrm{Fe}+\mathrm{PGA}+ \\
\text { cyanocobalamin } \\
+ \text { ascorbic acid }\end{array}$ & 55 & $63 \cdot 6$ & $63 \cdot 1$ & -0.5 & $2 \cdot 235$ & 0.09 (NS) \\
\hline 3 & $\begin{array}{l}\mathrm{Fe}+\mathrm{PGA}+ \\
\quad \text { cyanocobalamin } \\
\quad+\text { protein }\end{array}$ & 55 & $65 \cdot 6$ & $60 \cdot 8$ & -4.8 & $2 \cdot 319$ & $<0.05$ \\
\hline
\end{tabular}

PGA, Pteroylmonoglutamic acid; NS, not significant.

view, there would appear to be no advantage in adding ascorbic acid to therapeutic $\mathrm{Fe}$ supplementation with doses of $\mathrm{Fe}$ of the order employed in this study.

The daily supplement of $\mathrm{I} 5 \mathrm{~g}$ protein, as calcium caseinate, given together with the $\mathrm{Fe}$, pteroylglutamic acid and cyanocobalamin resulted in a significantly greater rise in mean haemoglobin concentration, packed cell volume and MCHC, than in the other two groups. The reasons for the better response in this group of women are not clear. There appear to be two possible explanations. These women mostly came from the lower socio-economic strata, and their protein intake was at best marginally adequate (Rao \& Rao, 1958; Mathan, I 971), and it is possible that this affected haematopoiesis. In experimental animals, severe protein deficiency, without deficiency of other haemopoietic substances, consistently results in anaemia (Sood et al. 1965). In man severe protein-energy malnutrition is usually associated with anaemia, although the extent to which this is due to protein deficiency or deficiency of other nutrients is not always clear (Adams \& Scragg, 1965; Pereira \& Baker, 1966; Viteri et al. 1968). To date there is no evidence in humans that marginal protein deficiency is a limiting factor in haematopoiesis. The other possibility is that the administration of calcium caseinate improved Fe absorption. Diets rich in phytates reduce Fe absorption (Hussain \& Patwardhan, 1959) and although it has never been demonstrated, it is theoretically possible that increased calcium intake will reduce the inhibitory effect of the phytates. Alternatively, increased Fe absorption could be due to an enhancing effect of the protein, as has been shown with smaller amounts of Fe for veal muscle (Martinez-Torres \& Layrisse, I97I), fish (Layrisse et al. 1974), and amino acids (Martinez-Torres \& Layrisse, 1970). The finding that the increase in MCHC was significantly greater in group 3 suggests that the latter explanation may be more likely to be the correct one, even though the rise in serum $\mathrm{Fe}$ and transferrin saturation in this group were not significantly greater than in the other groups. Nevertheless, these explanations are hypothetical and a full explanation of the results awaits further elucidation. The significant decrease in concentration of serum proteins in the protein-supplemented group (group 3), which was not seen in the other two groups, remains an unexplained observation, and perhaps further suggests that the antianaemic effect was not due to an over-all improvement in protein nutrition.

Even in group 3 where the best results were achieved, $23.5 \%$ of the women were still anaemic at the end of the trial (haemoglobin less than $110 \mathrm{~g} / 1$ ). In all groups, at the end of the period of supplementation, the mean values of the $\mathrm{MCHC}$, the serum $\mathrm{Fe}$ and the 
percentage saturation of transferrin were low, indicating a persisting high prevalence of Fe deficiency. This confirms the finding of the previous study (Sood et al. 1975) that the major cause of anaemia in pregnant women in India is Fe deficiency.

The authors wish to express their indebtedness to the nursing, technical and secretarial assistants who made this study possible and to Glaxo, India, Ltd for the gift of cyanocobalamin and calcium caseinate used in this study, and are grateful to Dr M. Behar and Dr E. M. DeMaeyer of the Nutrition Division, WHO, for their help and encouragement.

\section{REFERENCES}

Adams, E. B. \& Scragg, J. N. (1965). Br. J. Haematol. rx, 676.

Apte, S. V. \& Venkatachalam, P. S. (1965). Indian J. med. Res. 53, 1084.

Björn-Rasmussen, E. \& Hallberg, L. (1974). Nutr. Metab. 16, 94.

Dacie, J. V. (1956). Practical Haematology, 2nd ed. London: Churchill.

Hallberg, L., Solvell, L. \& Brise, H. (1966). Acta med. scand., 175, Suppl. 459, I I.

Herbert, V., Gottlieb, C. W., Lau, K. S., Fisher, M., Gevirtz, N. R. \& Wasserman, L. R. (I966). J. Lab. clin. Med. 67, 855 .

Hussain, R. \& Patwardhan, V. N. (1959). Indian J. med. Res. 47, 676.

International Committee for Standardization in Haematology (I97I). Br. J. Haematol. 20, 45 I.

Layrisse, M., Martinez-Torres, C. \& Gonzalez, M. (1974). Am. J. clin. Nutr. 27, I 52.

Martinez-Torres, C. \& Layrisse, M. (I970). Blood 35, 669.

Martinez-Torres, C. \& Layrisse, M. (197I). Am. J. clin. Nutr. 24, 531.

Mathan, V. I. (I97I). Malabsorption syndrome. PhD Thesis, University of Madras.

Pereira, S. M. \& Baker, S. J. (1966). Am. J. clin. Nutr. 18, 413.

Rao, B. R. H. \& Rao, P. S. S. (1958). Indian J. med. Sci. 12, 726.

Sayers, M. H., Lynch, S. T., Jacobs, P., Charlton, R. W., Bothwell, T. H., Walker, R. B. \& Mayer, F. (I973). Br. J. Haematol. 24, 209.

Sood, S. K., Deo, M. G. \& Ramalingaswami, V. (1965). Blood 26, 42 I.

Sood, S. K., Ramachandran, K., Mathur, M., Gupta, K., Ramalingaswami, V., Swarnabai, C., Ponniah, J., Mathan, V. I. \& Baker, S. J. (1975). Q. Jl Med. 44, 24 I.

Viteri, F. E., Alvarado, J., Luthringer, D. G. \& Wood, R. P. (I 968). Vitams. Horm. $26,573$. 